\title{
The role played by implant surfaces during the healing and the maintenance of soft tissue
}

\begin{abstract}
In the last twenty years dental research deeply studied the interaction between bone and implant surface, in order to understand and positively affect the osseointegration process. The important item deal with is the interaction between implant surface and soft tissues, though about that few papers are available. The aim of this paper is to deepen the nature of these interactions with the help of main scientific database and in particular of a series of articles produced by Department of fixed prosthodontics of University of Genova.
\end{abstract}

Keywords: implant, surface, soft tissues, bone
Volume 7 Issue 2 - 2017

\author{
Baldi Domenico, Pera Paolo, Colombo \\ Jacopo \\ Department of Fixed and Implant Prosthodontics, University of \\ Genova, Italy
}

Correspondence: Jacopo Colombo, Faculty of Medicine, Department of Fixed and Implant Prosthodontics, University of Genova, Genova, Italy, Tel 390187716585,

Email jacopocolo@tiscali.it

Received: April II, 2017 | Published: April 21, 2017

\section{Discussion}

Dental literature shows a relevant interest about the properties of implant surfaces and molecular mechanisms which occur at the interface between bone and peri-implant soft tissues. To evaluate the biological behaviour of the host's tissues at the interface with the implant we need to consider fixture microtopography and its superficial chemical structure. Dental implants present diverse superficial morphologies. At the beginning of modern dental implantology only smooth surfaces known as "machined surfaces" were available. Later researchers designed rough surfaces with the aim of increasing the contact area between bone and implant so that a sort of micromechanical retention was established (Table 1) finally, it was evident that superficial roughness not only affects the dimension of the area dimensions but can become a modulating tool for cell activity and differentiation. In vitro research demonstrated that microscopic topography of the implant surface could play a leading role in osteoblastic activity and differentiation. Cells of mesenchimal origin interact, through the focal adhesion of their cytoskeleton, wit proteins which are absorbed on a titanium surface. This process of adhesion is activated by integrin, which are adhesive proteins allowing adhesion of cells to a substrate. The number and the distribution of these contact points can affect the cell's genic expression. So it is clear how microtopography can affect shape, pattern of migration and differentiation of cells. ${ }^{1}$ Different processes which are used to modify a surface topography also affect the chemical structure of the surface itself. In detail, the pro-cess of acid etching purifies an implant surface through removal of titanium external layers and with them of most of carbonium remnants which are left as sediment after titanium turning. A paper by Morra et al. ${ }^{2}$ showed a high percentage of carbonium present on the machined surface of a smooth fixture- $66 \%$ compared to a fixture which is processed with a double acid etching; in this case they recorded a lower percentage of $\mathrm{Ca}-42,2 \%$ The implant Nanotite (Biomet 3i) shows a further reduction of the percentage of superficial carbonium $(35,1 \%)$. It is made of a titanium alloy Ti6Al4V and consequently on its surface there is a high content of Alluminum $(0,6 \%)$, Calcium and $\mathrm{P}$ due to the release of nanocrystals of Calcium Phosfate on the surface, which is a peculiar feature of this implant. Unfortunately there is a lack of interest in the interaction be-tween modified surfaces and peri-implant soft tissues and so few papers on the subject are available. From this literature we learn that connective tissue and the epithelium can create a bond with the titanium of the implant surface suggesting that good health and resistance to peri-implant disease could be thanks to this state of "tissue integration". During the Nineties researchers thought that rough surfaces could allow a bacterial adhesion 25 times higher than machined ones and so favour the onset of periimplantitis. They also assumed in consequence that a sort of reduced roughness was essential to delay the appearance of plaque and its maturation. Baldi et al. ${ }^{4}$ evaluated soft tissue reaction to smooth and rough surfaces; this was performed in vivo using special healing screws whose surface was rough. In detail, after insertion of Full Osseotite implants (with no smooth collar), abutments with an etched surface were screwed on; the other group had Osseotite implants, with a smooth collar, onto which traditional smooth abutments were screwed. Through this procedure the authors believed they had simulated a peri-implant recession; whereas actually the two evaluated surfaces were not only in contact with bone but also with peri-implant soft tissues and were freely exposed in the oral cavity (Table 2). The Anova test did not show any statistical difference in bone reabsorption considering the two study groups; even in the population of fully etched implants they recorded less bone re-absorption com-pared to the population of hybrid implants with a smooth collar, after 24 and 36 months following surgery. From this paper we learn that fully etched implants allow long term maintenance of bone integrity even when immediate loading protocols are applied, in this case coupled with the Columbus Bridge prosthetic protocol (Table 3 \& 4) (Figure 1-4). Therefore fully etched surfaces positively affect bone healing around implants and this effect prevails against that of a higher plaque retention which occurs when some implant threads are exposed in the oral cavity. ${ }^{5-13}$ 
Table I Most common implant surface treatment

\begin{tabular}{ll}
\hline \multicolumn{2}{l}{ Modifing process of implant surface } \\
\hline Turning & Machined surfaces \\
Sandblasting & $\mathrm{Al}_{2} \mathrm{O}_{3} ; \mathrm{ZrO}_{2} ; \mathrm{TiO}_{2} ; \mathrm{SiC}$ \\
Oxidation & Galvanic bath \\
Etching & $\mathrm{HF} ; \mathrm{HCl} ; \mathrm{H}_{2} \mathrm{SO}_{4}$ \\
Apposition & Plasma-spray; $\mathrm{HA}$ \\
Nanotechnologies & nanometric surface changes \\
Bioengineering & surface ability of interaction with surrounding biologic substratum
\end{tabular}

Table 2 Surface composition (\% atomic) obtained by XPS analysis

\begin{tabular}{lllllllllll}
\hline Campione & $\mathbf{C}$ & $\mathbf{O}$ & $\mathbf{T i}$ & $\mathbf{N}$ & $\mathbf{S}$ & $\mathbf{S i}$ & $\mathbf{P}$ & $\mathbf{C a}$ & $\mathbf{A l}$ & $\mathbf{C l}$ \\
\hline Machined & $66, \mathrm{I}$ & 22,3 & 8,6 & 0,6 & & $\mathrm{I}, 8$ & & & & 0,6 \\
Osseotite & 42,2 & 33,5 & 18,1 & 0,8 & 0,5 & 2,1 & 0,4 & 0,4 & & \\
Full Osseotite & 42,2 & 36,6 & 18,8 & 0,9 & 0,1 & $\mathrm{I}, \mathrm{I}$ & & 0,3 & & \\
NanoTite & $35, \mathrm{I}$ & 34,9 & 6,4 & 0,5 & & 0,7 & 7,5 & 14,3 & 0,6 & \\
\hline
\end{tabular}

Table 3 Values in millimeters; $M$, mesial site; $D$, distal site

\begin{tabular}{lllllllll}
\hline \multicolumn{3}{l}{ Full osseotite implants } & \multicolumn{5}{l}{ Osseotite implants } \\
\cline { 2 - 8 } & Time & M & D & Media & M & D & Media \\
\hline $\mathrm{T}_{0}$ & 0,57 & 0,44 & 0,5 & 0,69 & 0,22 & 0,45 \\
$\mathrm{~T}_{12}$ & $\mathrm{I}, 39$ & $\mathrm{I}, 3$ & $\mathrm{I}, 35$ & $\mathrm{I}, 35$ & $\mathrm{I}, 23$ & $\mathrm{I}, 29$ \\
$\mathrm{~T}_{24}$ & $\mathrm{I}, 52$ & $\mathrm{I}, 3 \mathrm{I}$ & $\mathrm{I}, 4 \mathrm{I}$ & $\mathrm{I}, 69$ & $\mathrm{I}, 47$ & $\mathrm{I}, 58$ \\
$\mathrm{~T}_{36}$ & $\mathrm{I}, 6$ & $\mathrm{I}, 48$ & $\mathrm{I}, 54$ & $\mathrm{I}, 66$ & $\mathrm{I}, 63$ & $\mathrm{I}, 65$ \\
\hline
\end{tabular}

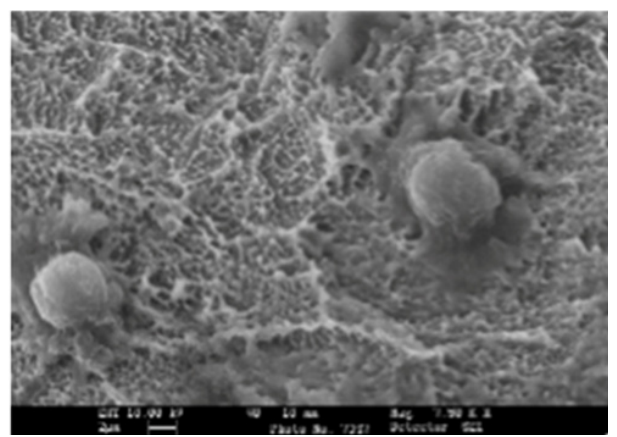

Figure I Osteoblasts after 6 hours of culture on a Osseotite surface (double acid etch surface).

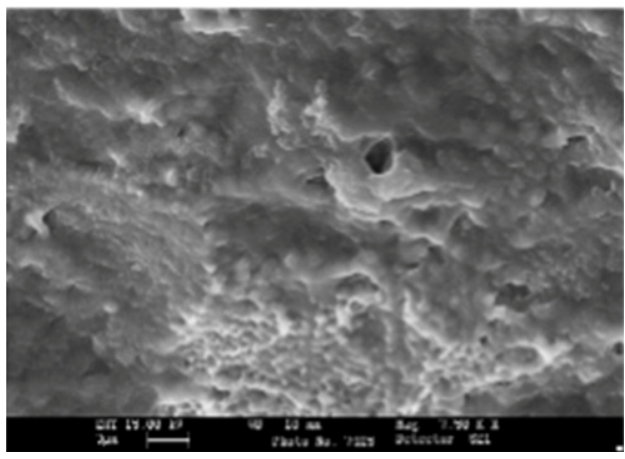

Figure 2 Osteoblasts after 24 hours of culture.

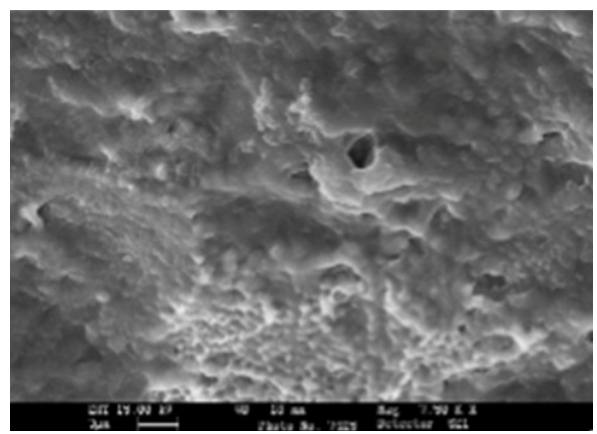

Figure 3 Osteoblasts after 72 hours of culture.

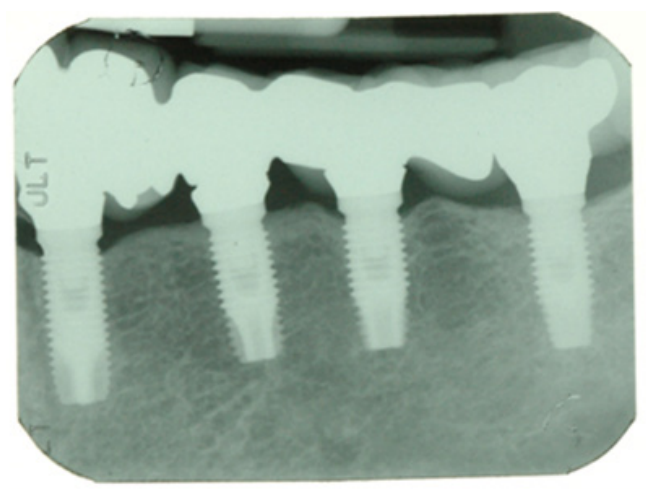

Figure 4 Periimplant bone misuration.

Citation: Domenico B, Paolo P, Jacopo C. The role played by implant surfaces during the healing and the maintenance of soft tissue.J Dent Health Oral Disord Ther. 2017;7(2):25 I-253. DOI: 10.15406/jdhodt.2017.07.00232 


\section{Acknowledgments}

None.

\section{Conflicts of interest}

The authors declare there is no conflict of interest.

\section{References}

1. Conserva E, Menini M, Pera F, et al. The role of surface implant treatments on the biological behavior of SaOS-2 osteoblast-like cells. An in vitro comparative study. Clin Oral Implants Res. 2012;24(8):880-889.

2. Morra M, Cassinelli C, Bruzzone G, et al. Surface chemistry effects of topographic modification of titanium dental implant sur- faces. 1: Surface analysis. Int J Oral Maxillofac Implants. 2003;18(1):40-45.

3. Quirynen M, Van der Mei HC, Bollen CM, et al. An in vivo study of the influence of thesurface roughness of implants on the microbiology of supra- and subgingival plaque. $J$ Dent Res. 1993;72(9):1304-1309.

4. Lindhe J, Berglundh T, Ericsson I, et al. Experimental breakdown of peri-implant and periodontal tissues. A study in the beagle dog. Clin Oral Implants Res. 1992;3(1):9-16.

5. Baldi D, Menini M, Pera F, et al. Plaque accumulation on exposed titanium surfaces and peri-im- plant tissue behavior a preli- minary 1-year clinical study. Int J Prosthodont. 2009;22(5):447-450.

6. Tealdo T, Bevilacqua M, Pera F, et al. Periimplant bone radiographic evaluation around smooth and rough implant surfaces. A 36 months retrospective follow-up study. J Prosth. 2011.
7. Tealdo T, Bevilacqua M, Pera P. Columbus Bridge Protocol. Quintessence, Milan, Italy, 2009:1-388.

8. Zetterqvist L, Feldman S, Rotter B, et al. A prospective, multicenter, randomized-controlled 5-year study of hybrid and fully etched implants for the incidence of peri-implantitis. J Periodontol. 2010;81(4):493-501.

9. Menini M, Dellepiane E, Baldi D, et al. Microarray expression in periimplant tissue next to different titanium implant surface predicts clinical outcome. A Split mouth study. Clin Oral Implants Res. 2017;28(9):e121e134.

10. Menini M, Dellepiane E, Chvartszaid D, et al. Influence of Different Surface Characteristics on Peri-implant Tissue Behavior: A Six-Year Prospective Report. Int J Prosthodont. 2015;28(4):389-395.

11. Menini M, Piccardo P, Baldi D, et al. Morphological and chemical characteristics of different titanium surfaces treated by bicarbonate and glycine powder air abrasive systems. Implant Dent. 2015;24(1):47-56.

12. Baldi D, Longobardi $M$, Cartiglia $C$, et al. Dental implants osteogenic properties evaluated by cDNA microarrays. Implant Dent. 2011;20(4):299-305.

13. Vercellotti T, Stacchi C, Russo C, et al. Ultrasonic implant site preparation using piezosurgery: a multicenter case series study analyzing 3,579 implants with a 1- to 3-year follow-up. Int J Periodontics Restorative Dent. 2014;34(1):11-18. 